\title{
Nationalism in National \\ Geographic Magazine, 1888-1923
}

\author{
Natalie A. Schumann, The Media School, Indiana University Bloomington
}

\section{ABSTRACT}

7 he National Geographic Magazine was first published in October 1888. Its mission statements both at the time of inception and in 1 present day reflect an effort to bring the world to American readers, as well as its aim to educate and inform readers about other countries, species, and cultures. However, during the magazine's first three decades in print, the United States underwent major changes and was rapidly developing into one of the world's most powerful nations. National Geographic heavily covered three specific events during this time period: the Spanish-American War, the colonization of Cuba and the Philippines, and the creation of the first national parks. This coverage presented readers with strong nationalist opinions that broadcast views of American superiority. In this analysis of those early articles, the magazine's nationalist sentiments become evident through primary and secondary examples, and its original and current mission statements are brought into question. The National Geographic readers know today was once a very different publication due to its reflection of current events and a changing American attitude toward other countries.

KEYWORDS: media bias, American exceptionalism, nationalism, colonialism, political ideology

\section{INTRODUCTION}

The first issue of National Geographic Magazine (NGM) was published in 1888, shortly after the inception of the National Geographic Society. The magazine has brought investigations and general coverage of the world outside the United States to its readers for more than 100 years, highlighting such topics as nature, wildlife, conservation, and most importantly, people of different cultures. In an examination of NGM feature stories published between 1888 through the first two decades of the $20^{\text {th }}$ century (the magazine's first three decades in print), the magazine's nationalist sentiments become strikingly evident. Three notable early- $20^{\text {th }}$ century events concerning American nationalism include the Spanish-American War, the colonization of the Philippines and Cuba, and the establishment of the National Park Service. All were covered heavily in NGM articles. Through coverage of these three events, the magazine disseminated a predetermined American attitude toward other countries and territories to its readers, and also encouraged national pride by explicitly highlighting only the best features of its readers' home.

\section{THE FOUNDATIONS OF NGM}

In the opening statement of the very first issue of National Geographic Magazine, the society states that it "has been organized 'to increase and diffuse geographic knowledge"' (Hubbard, 1888, p. 3). In 2015, the current mission statement of NGM is "to inspire people to care about the planet" (Potts, 2014). The mission statements, although slightly different, indicate that the Society and magazine have generally maintained the principles and ideals on which they were founded. However, upon close examination of the magazine's content during its first three decades, both of these mission statements seem less applicable. As the Society was developing and growing, so was the United States as a global force. According to the original introduction in the first issue, the Society and its publication began with strictly scientific motives and goals. As the country's role across the globe changed, so did the goals of the Society (Schulten, 2000). In 1896, newly appointed editor John Hyde communicated with readers the changing mentality of the magazine. "It will accordingly be the aim of the National Geographic Magazine to be American rather than cosmopolitan, and in an especial degree to be National," Hyde wrote to readers in his introductory address (Hyde, 1896, pp. 6-8).

Hyde continued to detail the connection between the United States and the "countries in which the people of the United States are now taking an exceedingly 
keen and friendly interest" (Schulten, 2000, p. 13). The address as a whole was quite patriotic and nationalist in sentiment, as Hyde was prideful regarding NGM's role in American and foreign lives. In Philip J. Pauly's analysis of the Society's foundations, he recalled Alexander Graham Bell's words regarding the main idea of the magazine: "The world and all that is in it is our theme" (Pauly, 1979, p. 523).

As geography, science, and the United States' role across the globe became ever more intertwined, NGM's content moved gradually away from strictly scientific reports to an increasingly human-influenced view of the natural world. More than a decade after the initial inception of the Society, Hyde (1899) reflected similar sentiments in his article "The National Geographic Society," published in June of that year. Hyde (1899) wrote:

For the first time in its history a systematic effort is about to be made to increase its membership, as the first step toward the enlargement of its work, and if each member will recognize his obligation-if not to the Society as an organization, at least to the cause with which it is identified, the closing year of the century will see the National Geographic Society enter upon a career of usefulness unexceeded in its far-reaching importance by that of any other scientific society in the world. (p. 220)

Hyde's (1899) view was echoed by Susan Schulten's (2000) explanation of the rising popularity of NGM:

\begin{abstract}
Many geographers-concerned about creating and defining their discipline within the university-were self-consciously academic in their approach to the subject; by contrast, the Geographic adopted a more general interest approach, with wildly successful results. As the Society declined as a predominantly local and scientific organization, it became ever more popular with the American public. (p. 9)
\end{abstract}

In just a decade, the Society and NGM expanded their production and readership was increasing rapidly. Therefore, the platform from which NGM could project ideas onto the American public continued to grow. This growth occurred just as the United States was engaged in an ongoing debate regarding colonialism.

\section{ANNEXATION, IMPERIALISM, AND COLONIALISM IN NGM}

Although cautionary views regarding colonialism were not uncommon, NGM articles included particularly nationalist-oriented views in several instances. In a December 1897 issue of NGM, Gannett (1897) wrote:

The United States, of all nations, should go very slowly in this matter, first, because since it stands at the head of the nations in point of civilization, almost any addition of people to its numbers will reduce the average civilization, and consequently the strength and industrial capacity of its people ... and third, because all annexations involve responsibilities in case of war for which we are unprepared and show little disposition to prepare ourselves. (p. 354)

This was published prior to any conflict in Cuba or the Philippines-both areas under scrutiny at the start of the $20^{\text {th }}$ century. The Spanish-American War occurred in 1898 and as a result the United States gained power over the Philippines. Filipino citizens rebelled and so began the Philippine-American War, lasting from 1899-1902 (U.S. Department of State, 2014). This article contains strong opinions on American superiority, prior to any real demand for the release of such a viewpoint, as the country was not embroiled in any imminent conflicts at the time of publication. Gannett's (1897) observations of United States' prominence on the world stage do not reflect the magazine's original or current mission statements. Rather, Gannett's (1897) article as a whole reflected American superiority and encouraged readers to be cautious when considering the addition of foreign people to the United States.

In an analysis of the magazine's adherence to Bell's 'the world and all that is in it' claim, historian Philip J. Pauly (1979) described the magazine's perceived attitude toward other countries:

Nonpartisanship and kindliness were synonymous with conservatism and the justification of colonialism. Everything unpleasant about a situation was left out, and if a group of people were controversial, they were not featured. Thus from 1905 to 1920 only those countries sufficiently distant and exotic to be independent of American standards of proper behavior were featured in the Geographic ... Immigrants to America trod across the pages of the Geographic in colorful costume until they left Ellis Island; after that point they disappeared. (p. 528) 
Pauly's (1979) account effectively summarizes American attitudes as seen in NGM articles regarding Cuba, the Philippines, and other foreign lands and countries. The articles selected only certain aspects of the colonized or otherwise foreign lands and almost always painted the United States in a positive light.

\section{CUBA AND THE SPANISH-AMERICAN WAR}

The Spanish-American War was the first large conflict involving the United States and another country that was covered by NGM. In the May 1898 issue, a feature article written by Robert T. Hill opened with a large photo of Captain Charles D. Sigsbee, the U.S. Naval captain who was aboard the USS Maine when it was attacked in Havana Harbor (Schulten, 2000, p. 14). While the article itself was a detailed account of the island of Cuba and its qualities, it also contained a notable tribute to Sigsbee. The tribute, written by Gannett, detailed Sigsbee's heroism as a member of the Navy as well as his role as part of the Society. He aided efforts to expand and advance deep-sea exploration. John Hyde also wrote about the reception for Sigsbee in the same package, which further injects nationalist spirits into an article seemingly centered on the simple analysis and exploration of a foreign country (Hyde, 1898). Sigsbee's dominating presence in the article is difficult to ignore.

In another article about Cuba, NGM described in great detail the features of the Isle of Pines, a separate island that also belonged to the country. The article concludes with a section titled "Possibilities of Development" (Wilson, 1906). Rather than simply educating readers about the features and characteristics of the Isle of the Pines, the article highlighted the ways in which the island could benefit the United States. Coverage depicting Cuba as a possession or commodity was common, as many articles from this time period demonstrated. One such article detailed the economic prospects of Cuba and other islands, and is accordingly titled "Our New Possessions and the Interest They are Exciting" (Austin, 1900). In 1907, Secretary of War William Howard Taft published a piece in the July issue of NGM titled "Some Recent Instances of National Altruism." Taft (1907) began with the following statement:

I ask your attention today to the page of the nation's history covering the last nine years, with the hope of showing that there never has been on the part of any country a greater exhibition of pure altruism than that exhibited by the United States from the beginning of the Spanish War down to the present day, toward the peoples who were immediately affected. (p. 429)

Taft continued to mention President Roosevelt's 1903 speech, in which Roosevelt referred to Cuba as a "weak" young republic in need of American assistance (Wilson, 1906). Although it was appropriate for Taft, as the Secretary of War, to have such nationalist views, the intense focus on American superiority throughout the article questions the views of $N G M$ as a neutral publication. Taft also highlighted American influence in the Philippines, which posed additional questions and conflicts about how the United States should handle global relationships and territory acquisitions.

\section{THE PHILIPP\|NES}

At the conclusion of the Spanish-American War, Spain was forced to transfer its power over the Philippines to the United States, which provided Filipinos with a chance to revolt. Although NGM had previously explored the islands for scientific purposes, the pieces published when this conflict arose reflected deep-seeded superiority sentiments. Schulten (2000) summarized:

The Geographic prepared its audience well for American stewardship of these territories. But this expansion of responsibility came with a recognition that they were inhabited by people that were utterly different and possibly less advanced than Americans. To allay these fears the Geographic repeatedly invoked the second goal of American internationalism, progressive uplift. (p. 17)

Schulten (2000) described in general terms NGM's views regarding the Philippines, as seen in several articles covering the topic. The United States, and evidently NGM, was concerned with the 'uplift' of the societies it influenced, suggesting that those societies were previously inferior to American societies. Additionally, Schulten commented on the government's influence on both public and scientific opinions of the Philippines (Schulten, 2000, p. 13). Due to lack of funds, the magazine relied heavily on government information 
and data about the region. Thus, an American bias would likely be formed due to the nature of reporting techniques.

NGM writer Frank Frederick Hilder published several articles about the Philippines between 1898 and 1901 during the key years of conflict. Most notably, he criticized the native and Spanish methods of mining the abundant gold found on the islands and deemed them "rudimentary" (Hilder, 1900, p. 465). Again, the Philippine islands were viewed as possessions or commodities, and the focus was placed on what the land can provide for the United States rather than on the unique cultures and people living there. The high frequency of articles about the Philippines, as seen in the many published by Hilder and others, suggests that $N G M$ was very involved in shaping readers' perceptions of the conflict surrounding the islands.

In 1905, several years after the United States had acquired the Philippines, then-editor of NGM Gilbert Hovey Grosvenor wrote an article titled "A Revelation of the Filipinos" (Grosvenor, 1905). He opened with a statement regarding how surprising the actual conditions in the Philippines were compared to the negative impressions Americans had originally formulated (Grosvenor, 1905). One section was headlined "Surprising Ability to Read and Write," and a large collection of photographs accompanied the text (Grosvenor, 1905). The entire piece was presented with a tone of surprise, as if Grosvenor found it difficult to believe that other nations could be developing as well as the United States.

Dean Worcester's November 1913 article, "NonChristian Peoples of the Philippine Islands," depicted native Filipinos as uneducated and very unfamiliar with the developed world (Worcester, 1913). A photo caption described young Filipino boys as "little savages" (Worcester, 1913, p. 1242), and Worcester later wrote, "From the early days of the appointment of American governors the wild men have come to them to have their difficulties settled, having soon learned to have an abiding faith in the honest and fairness of these officials" (Worcester, 1913, p. 1245). Through this writing, NGM portrayed the Philippines and its people as inferior to American citizens and publicized the government's role in permanently altering the native culture of the region.

\section{NATIONAL PARKS AND NATIONAL PRIDE}

While NGM obviously published works with nationalist views directed toward other countries and territories, the magazine also expressed pride in American lands. These sentiments were particularly evident throughout the establishment of the first national parks.

In the first decade of the $20^{\text {th }}$ century, NGM published numerous articles that centered on undiscovered Western lands, such as Alaska or the area now known as Glacier National Park. These articles were published prior to the establishment of the National Park Service, which was formed in 1916. Earlier that year, one notable article appeared in the April issue of the magazine. Written by Grosvenor (1916), it glorified the lands of North America on an epic scale. The entire article praises the superior landmarks and various areas of the country.

Traces of competition with other countries or of American superiority on a global scale were still evident: "It takes no undue amount of national pride to accept New York as the world's foremost metropolis ... nowhere else on the face of the earth is there a city of such many-sided greatness as New York" (Grosvenor, 1916, p. 337). This article applied national pride even to the bustling city of New York, whereas most articles related to National Parks describe wild, unsettled western lands. Grosvenor (1916) also wrote an overarching statement about the general grandeur of the United States, which exemplified the national pride promoted by the magazine:

But in that architecture which is voiced in the glorious temples of the sequoia grove and in the castles of the Grand Canyon, in that art which is mirrored in American lakes, which is painted in geyser basins and frescoed upon the side walls of the mightiest canyons, there is a majesty and an appeal that the mere handiwork of man, splendid though it may be, can never rival. (pp. 327-339)

In this description, Grosvenor (1916) represents both nationalism and the concept of manifest destiny, which was widespread across the United States in the beginning of the $20^{\text {th }}$ century. The magazine's current 
mission statement, "To inspire people to care about the planet" (Potts, 2014) is slightly more applicable here, but the theme of the article is still largely nationalist and errs on the side of American superiority. In additional articles and photography essays, such as "Western Views in the Land of the Best," the magazine celebrates the American landscape in a more visual way, thus showing readers the features of the country rather than relying on foreign reports (Clatworthy, 1923).

\section{CONCLUSION}

After examining these three main areas of NGM coverage in the early $20^{\text {th }}$ century, contradictions between the magazine's mission statements and coverage become obvious. The coverage examined - while the magazine was relatively fledgling - largely reflects United States development that occurred during that time. Articles about the Spanish-American War and the colonization of the Philippines and Cuba demonstrated the country's general superiority sentiments toward other countries, while articles about the National Parks demonstrated the country's pride in itself and the principle of manifest destiny. The magazine contributed to the political views of its readers and vice versa, but these articles clearly exhibit the magazine's nationalist tendencies, which do not entirely match up with the original or current mission statements. In conclusion, NGM articles from the early years of the Society should be read with a critical mindset, keeping in mind the nationalism that underlies many of its articles.

\section{ACKNOWLEDGMENTS AND CORRESPONDENCE}

The author would like to thank Gerry Lanosga for a very beneficial journalism history course, for encouraging the completion and submission of this article, and for editing assistance throughout the submission process.

All correspondence concerning this article should be addressed to Natalie A. Schumann at naschumann1@gmail.com

\section{REFERENCES}

Austin, O.P. (1900, January). Our new possessions and the interest they are exciting. The National Geographic Magazine, 11(1), 32.
Clatworthy, F.P. (1923, April). Western views in the land of the best. The National Geographic Magazine, 43(4), 1.

Gannett, H. (1897, December). The annexation fever. The National Geographic Magazine, 8(12).

Grosvenor, G.H. (1905, April). A revelation of the Filipinos. The National Geographic Magazine, 16(4), 139-192.

Grosvenor, G.H. (1916, January). Resources of our own country. The National Geographic Magazine, 29(1), 327-431.

Hilder, F.F. (1900, December). Gold in the Philippines. The National Geographic Magazine, 11(12), 465-470.

Hubbard, G. (1888, October). Introductory address. The National Geographic Magazine, 1(1).

Hyde, J. (1896, January). Introductory. The National Geographic Magazine, 7(1).

Hyde, J. (1898, May). Reception to Captain C.D. Sigsbee, U.S.N. The National Geographic Magazine, 9(5), 251-252.

Hyde, J. (1899, June). The National Geographic Society. The National Geographic Magazine, 10.

Pauly, P.J. (1979). The world and all that is in it: the National Geographic Society, 1888-1918. American Quarterly, 31(4), 517-532. doi:10.2307/2712270

Potts, M.A. (2014). About the National Geographic Society. Retrieved from: http://www. nationalgeographic.com/about/

Schulten, S. (2000). The making of the National Geographic: Science, culture, and expansionism. American Studies, 41(1), 5-29. Retrieved from: http://www.jstor.org/stable/40643115

Taft, W.H. (1907, July). Some recent instances of national altruism: the efforts of the United States to aid the peoples of Cuba, Puerto Rico, and the Philippines. The National Geographic Magazine, $18(7), 429-438$.

U.S. Department of State (2014). Milestones, 18991913. Retrieved from: http://history.state.gov/ milestones/1899-1913/war

Wilson, H.W. (1906, February). Isle of Pines. The National Geographic Magazine, 17(2), 105-108.

Worcester, D.C. (1913, November). The non-Christian peoples of the Philippine Islands. The National Geographic Magazine, 24(11), 1157. 